\title{
The impact of board of directors' characteristics and remuneration on companies' performance in Malaysia
}

\begin{abstract}
This study aims at investigating the impact of board size, board independence, CEO duality, board gender diversity and board remuneration on the performance of public listed firms in Malaysia. Using the fixed effect and random effect models, the result showed that board independence and board remuneration have positively influenced firm performance respectively to ROA and TQ. However, board gender diversity was negatively associated with ROA. These results imply that higher number of board independence and higher amount of board remuneration can enhance firm performance. Though the Malaysian Code of corporate governance, the importance of having more female on board with the quota of $30 \%$ has been stressed with the result apparently presented that many female representations on the board may not enhance but deteriorate firm performance. The result of this study supported the notion of board remuneration and board independence that act as effective governance mechanisms to mitigate agency cost. With these results, firms must carefully design the director remuneration and determine appropriate numbers of independent director and female director on the board since they can influence firm performance.
\end{abstract}

Keyword: Board independence; Board gender diversity; Board remuneration; Return on assets; Tobin's Q; Fixed effects model; Random effects model 